\title{
The importance and distinctiveness of small-sized phytoplankton in the Magellan Straits
}

\author{
Adriana Zingone $\cdot$ Diana Sarno $\cdot$ Raffaele Siano $\cdot$ \\ Donato Marino
}

Received: 25 May 2010 / Revised: 29 October 2010 / Accepted: 29 November 2010 / Published online: 23 December 2010

(C) The Author(s) 2010. This article is published with open access at Springerlink.com

\begin{abstract}
The distribution of summer phytoplankton across the Straits of Magellan (SOM) was studied with the aims of tracing differences among the distinct subregions of the area and contributing to the knowledge of its biodiversity. Samples collected at 25 stations were observed and counted in light microscopy. Selected samples were observed with transmission electron microscopy. The main unifying feature of the phytoplankton in the SOM was the high abundance and numerical dominance of small-sized $(<10 \mu \mathrm{m})$ eukaryotic species, among which coccoid cells of $<3 \mu \mathrm{m}$ size were predominant $(56.2 \pm 30.6$ of the total phytoplankton abundance). They mostly belonged to the prasinophyte Pycnococcus provasolii, which was abundant $\left(0.8-6,834\right.$ cells $\left.\times 10^{3} \mathrm{ml}^{-1}\right)$ at all stations with the exception of those in proximity to the Atlantic entrances, where it
\end{abstract}

The deeply missed Donato Marino (1948-2002) joined with great enthusiasm the 1991 and 1995 cruises in the Straits Magellan, collecting the material for this study and leading the first analyses of the data.

A. Zingone $(\bowtie) \cdot$ D. Marino

Ecology and Evolution of Plankton, LEEP,

Stazione Zoologica Anton Dohrn, Villa Comunale,

80121 Naples, Italy

e-mail: adriana.zingone@szn.it

D. Sarno $\cdot$ R. Siano

Taxonomy and Identification of Marine Phytoplankton, TIMP, Stazione Zoologica Anton Dohrn, Villa Comunale,

80121 Naples, Italy

Present Address:

R. Siano

IFREMER, Centre de Brest, DYNECO/Pelagos,

BP 7029280 Plouzané, France was not recorded. Small-sized $(<3$ and 3-5 $\mu \mathrm{m})$ diatoms (Minidiscus trioculatus, Lennoxia faveolata and other undetermined centric species) attained high densities $\left(<3,757\right.$ cells $\left.10^{3} \mathrm{ml}^{-1}\right)$ especially at stations of the Patagonian sectors, whereas microplanktonic diatoms were only found at the two entrances of the Straits. Dinoflagellates were constituted mainly by $>10 \mu \mathrm{m}$ forms in the Andean subregion and $<10 \mu \mathrm{m}$ naked species in the Patagonian subregion, contributing up to 75.9 and $41.8 \%$ of the total carbon in these two areas, respectively. In the Patagonian subregion, flagellates mainly constituted by $<5 \mu \mathrm{m}$ forms and by cryptomonads $<10 \mu \mathrm{m}$ comprised up to $53.9 \%$ of the total biomass. Several species identified in this study have never been reported in other investigations in the SOM, while others, including Pycnococcus provasolii and Lennoxia faveolata, have rarely been recorded elsewhere. Overall, the summer phytoplankton of the Straits does not resemble that of any other region of the world's seas. Although some of the predominant species might have been overlooked elsewhere, their abundance and relative importance apparently constitute a distinctive feature of the SOM.

Keywords Lennoxia faveolata - Periantarctic areas · Picoeukaryotes $\cdot$ Pycnococcus provasolii . Size structure

\section{Introduction}

Marine phytoplankton is extremely dependent on environmental factors which can cause space and time variations in their abundance, species composition and size ranges. The profound phylogenetic diversity of phytoplankton is reflected in an astonishing variety of morphological and biological features which cause individual phytoplankton 
species to show different responses to resource availability, environmental stimuli, predators and interspecific competition. Ultimately, the rates and pathways through which phytoplankton affects geochemical and trophic changes are strictly dependent on species composition (Cloern 1996). The Straits of Magellan (SOM), with its complex geomorphology and distinct climatic conditions (Antezana 1999), offers a unique opportunity to study phytoplankton in an environment characterised by a remarkable hydrographic and biological heterogeneity.

Early phytoplankton studies in the SOM focused on fjords or limited parts of the Straits (Lembeye et al. 1978; Uribe 1991; Iriarte et al. 1993), where blooms of Alexandrium catenella causing Paralytic Shellfish Poisoning (PSP) and discolourations produced by Gymnodinium sp. were reported (Guzmán et al. 1975; Lembeye et al. 1975; Uribe 1988a, b; Uribe and Ruiz 2001). An extensive study across the SOM in October-November 1989 provided first information on spring phytoplankton assemblages (Cabrini and Fonda Umani 1991; Uribe 1991), which were further analysed in subsequent investigations (Antezana et al. 1996; Iriarte et al. 2001). Phytoplankton studies were also conducted in other seasons, including the summer of 1991 (Carrada et al. 1994; Saggiomo et al. 1994; Magazzù et al. 1996) and the autumn of 1995 (Iriarte et al. 1996; Magazzù et al. 1996; Vanucci and Mangoni 1999).

The seasonal cycle of phytoplankton in the SOM shows a switch from large, micro and nanoplanktonic species during the seasonal blooms to small sized, ultra and picophytoplankton $(<5$ and $<2 \mu \mathrm{m}$, respectively) during the rest of the year (Iriarte et al. 2001). In this respect, the phytoplankton of the Straits resembles that of the Chilean coasts (Toro 1985; Iriarte et al. 2007) as well as of temperate (Li 2002) and Southern Ocean systems (Boyd 2002). The spring bloom is observed in October-November (Cabrini and Fonda Umani 1991; Iriarte et al. 2001) and is due to the proliferation of several colonial diatom species such as Chaetoceros compressuss, C. lorenzianus, C. debilis, Leptocylindrus danicus, Thalassiosira angulata, T. aestivalis, Pseudo-nitzschia spp. and Asterionellopsis glacialis (Antezana et al. 1996), most of which are cosmopolitan. In late summer and early autumn, the smallest size fraction $(<2 \mu \mathrm{m})$ is predominant (Saggiomo et al. 1994; Carrada et al. 1994; Iriarte et al. 1996; Magazzù et al. 1996; Iriarte et al. 2001) and cyanobacteria (Synechococcus and Prochlorococcus) constitute its major part (Bruni et al. 1993; Vanucci and Mangoni 1999). The picoeukaryotic fraction, which is also abundant in these seasons (Saggiomo et al. 1994; Vanucci and Mangoni 1999), is much less known, as it is generally dominated by featureless or delicate species that are spoiled by formaline or lugol and are hardly identifiable in light microscopy.
In this study, we analyse phytoplankton species distribution in the different regions of the SOM during the late summer of 1991, which was shown to be characterised by the marked dominance of phytoplankton in the $<2 \mu \mathrm{m}(62 \%)$ and 2-10 $\mu \mathrm{m}(33 \%)$ size fractions (Saggiomo et al. 1994; Magazzù et al. 1996). The aims of this paper are to verify whether the spatial heterogeneity of the SOM is reflected in variations of species assemblages and to contribute to the knowledge of the phytoplankton biodiversity in the area. Preliminary information on the data set collected in summer 1991 was provided by Marino et al. (1991; 1993). Since then, a number of investigations have addressed the SOM phytoplankton in other seasons (Vanucci and Mangoni 1999; Iriarte et al. 2001), as well as over the seasonal cycle (Iriarte et al. 2007; Avaria 2008). Yet, the data set collected in 1991 still holds information on the distribution of phytoplankton species that have rarely been explored in other studies. From our analysis, eukaryotic phytoplankton in the SOM appears to include several interesting smallsized species, which in some cases show differences in their spatial distribution across the SOM. Some of these species have rarely been recorded in other areas of the world's ocean, pointing at a peculiarity in the phytoplankton of the area and of its subregions.

\section{Materials and methods}

Study area

The Straits of Magellan (SOM) is a 550-km-long channel (Fig. 1) that represents a boundary area between the southern temperate and the Antarctic regions, as well as between the Atlantic and Pacific oceans, all of which have markedly different climatic and biological features. Due to the high variety of geographical features, the SOM has distinctive characteristics when compared to the other periantarctic areas, among which it is the only one having a continental nature.

Distinct subsystems can be identified in the SOM, in relation to the influence of the Atlantic and Pacific Oceans at the boundaries, the fjords opening southwards in the eastern portion and large and deep basins in western part. The exchange between these subsystems is limited due to the presence of sills and narrow passages, besides the roughly V-shaped structure of the channel (Fig. 1). From the climatological point of view, the SOM can be divided into two markedly different sections. The Andean section, from the Pacific entrance to Cape Froward, is subject to heavy rainfall $\left(400-2,000 \mathrm{~mm} \mathrm{year}^{-1}\right)$ and intensive runoff, with strong W-SW winds and a broad prevalence of cloudy days $(>8 / 10)$. The Patagonian section, from Cape Froward to the Atlantic, is characterised by lower rainfall 
Fig. 1 Map of the SOM with the location of the sampling stations and the identification of sectors $A-E$ following Saggiomo et al. (1994). Empty circles indicate the stations where phytoplankton was analysed at different depths

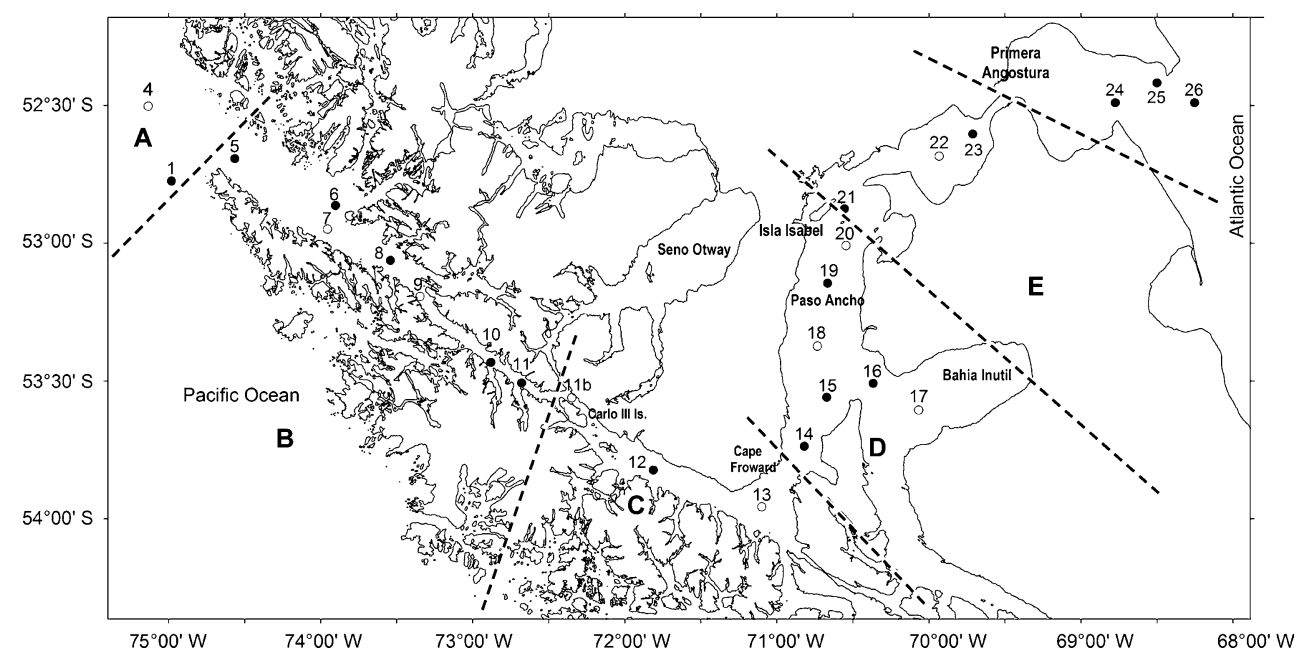

regime (250-300 $\mathrm{mm} \mathrm{year}^{-1}$ ) and hence reduced run-offs (Medeiros and Kjerfve 1988). Sea-water temperature over the year varies between 4 and $12^{\circ} \mathrm{C}$ at surface (Iriarte et al. 2001).

In summer 1991, different sectors were identified in the SOM (Fig. 1) based on distinct water density values, nitrate, POC and phytoplankton pigment distributions (Saggiomo et al. 1994; Carrada et al. 1994). Sector A includes shallow (max $200 \mathrm{~m}$ ), oligotrophic sites at the Pacific Ocean entrance, with vertically homogeneous phytoplankton pigments. Sector B, including stations west of Carlos III Island, is a deep (down to $1,100 \mathrm{~m}$ ) and narrow (ca $5 \mathrm{~km}$ ) channel characterised by a sharp pycnocline that originates from intense run-off (Artegiani et al. 1991) and by relatively rich phytoplankton biomass. Sector C, from Carlos III Island to Cape Froward, is a divergent shallow zone $(50 \mathrm{~m})$, the sill off Carlos III Island representing an obstacle to the hydrographic exchange between the adjacent sectors. In sector $\mathrm{C}$, the lowest chlorophyll $a$ (chl a) and POC values of the internal part of the SOM were found (Carrada et al. 1994), possibly due to light limitation caused by intense mixing, as nutrients were not limiting in that area (Saggiomo et al. 1994). The area from Cape Froward to Isabel Island (sector D) is rather shallow $(200 \mathrm{~m})$ and has a basin-like morphology. Stratification due to heat rather than run-off was observed in the area (Artegiani et al. 1991; Saggiomo et al. 1994). The highest chl $a$ concentrations were measured in this sector, where other phytoplankton pigments differed from those of the other sectors. These features, along with a marked pycnocline and an important decrease in nitrate within the euphotic layer, suggested a confined nature of this area, with a high residence time of the water masses (Saggiomo et al. 1994). Sector E (from Isabel Island to Primera Angostura) is a very shallow $(<50 \mathrm{~m})$ area, subject to strong tidal currents and consequent resuspension of sediments. The major component of the suspended matter is the inorganic fraction
(Fabiano et al. 1991). Despite the importance of tidal currents in this sector, biological, chemical and physical parameters exclude the hypothesis of a strong westward residual current of Atlantic origin during the stratified period (Saggiomo et al. 1994).

\section{Methods}

Phytoplankton samples were collected from 20 February to 3 March 1991 during a research cruise carried out on board of the R. V. Cariboo from the Pacific to the Atlantic boundaries of the SOM (Fig. 1). Twenty-five stations were sampled with bucket samples at surface; nine of them were also sampled with Niskin bottles at $10 \mathrm{~m}$ (22.5\% of the incident Photosynthetically Active Radiation, PAR) and at deeper layers corresponding to $8-1.7 \%$ of the incident PAR. Physical and chemical parameters, photosynthetic pigments, pico and zooplankton communities were also studied at these stations, and the results were presented elsewhere (Anonymous 1991; Faranda and Guglielmo 1993; Carrada et al. 1994; Saggiomo et al. 1994).

For quantitative analyses, samples were fixed with neutralised formaldehyde to a final concentration of $2.5 \%$. A number of surface samples were also fixed with glutaraldehyde to a final concentration of $1 \%$, to preserve the internal structure and to allow electron microscopy observations. All samples were preserved in dark glass bottles at a temperature of about $4^{\circ} \mathrm{C}$ until counting, which was completed within 6 months from the collection. Cell counts were performed at the inverted light microscope (LM) after sedimentation of variable sample volumes (2-100 ml), depending on cell concentration (Utermöhl 1958). Two transects, corresponding to ca $1 / 30$ of the whole bottom area of the sedimentation chamber, were analysed at $400 \times$ magnification. Coccoid species were counted on a variable number (mostly 20) of random fields, depending on their abundance. An average of 323 
$( \pm 176)$ specimens of the most abundant taxon and 755 $( \pm 298)$ specimens in total were counted in individual samples. Rare species found in either LM or EM observations were not quantified.

The principal taxonomic text used for species identifications were Throndsen (1993), Heimdal (1993), Hasle (1995) and Steidinger and Tangen (1995). Other papers used for identification of some species are reported in the text below. Microalgae that could not be identified to the species or genus level were included in suprageneric groups such as phytoflagellates, cryptophyceans, chrysophyceans, prasinophyceans, euglenophyceans, coccolithophores, centric diatoms, pennate diatoms, naked dinoflagellates and thecate dinoflagellates. The latter four groups were further subdivided according to cell size.

Biovolumes were calculated approximating cell shapes to basic or composite geometric solids. Linear cell dimensions were measured on an average of $50.7( \pm 28.6)$ cells for the 10 most abundant taxa, and on fewer specimens for the rest of the taxa, depending on their abundance and size variability. Taxa only recorded rarely or in electron microscopy, not included in cell counts, were not measured. Biovolumes were converted into carbon values using different formulas for protist plankton, diatoms $>3,000 \mu \mathrm{m}^{3}$ and other diatoms (Menden-Deuer and Lessard 2000). To compare cell size among taxa with different shapes, the equivalent spherical diameter (ESD) was calculated from the average biovolume of each taxon.

The Percentage Similarity Index (PSI) between pairs of phytoplankton samples was calculated with the formula suggested by Whittaker (1952), which takes into account the relative abundance of individual taxa in each sample.

Selected samples where small diatoms were particularly abundant were repeatedly washed with bidistilled water and mounted directly on grids for whole cell observation at Transmission Electron Microscopy (TEM). For TEM ultrastructural analysis, glutaraldehyde-fixed material was rinsed in $0.05 \mathrm{M}$ cacodylate buffer and post-fixed in buffered $2 \%$ osmium tetroxide. The material was then dehydrated in ethanol, transferred to propylene oxide and finally embedded in Epon resin, as detailed in Zingone et al. (1995). After polymerisation at $70^{\circ} \mathrm{C}$ for $24-35 \mathrm{~h}$, the samples were cut on a Reichert Ultracut ultramicrotome and ultrathin sections were observed using a Philips EM 400 microscope.

The identification of Pycnococcus provasolii was based on the original description of the species (Guillard et al. 1991). Samples collected in summer 1991 were subsequently compared with cultured material from the area of Paso Ancho obtained in the course of a cruise conducted in the autumn of 1995. Mixed cultures established with the serial dilution method (Andersen and Throndsen 2003) were observed in the light microscope. Selected cultures containing coccoid cells were fixed with $2 \%$ glutaraldehyde, post-fixed in osmium tetroxide and prepared for TEM observations as described above.

\section{Results}

Phytoplankton species

A total of 84 phytoplankton taxa and ataxonomic groups were identified in the Straits of Magellan in summer 1991 (Table 1). Of these, only a very restricted number constituted the bulk of the total phytoplankton. One of the most abundant species was a tiny (average $2.5 \mu \mathrm{m}$ ) coccoid form (Fig. 2a-d). Despite its small size and plain spherical shape, this species was distinguishable at LM due to the presence of two distinct chloroplasts, or two lobes of a single chloroplast, each with one refractive granule. At TEM, these granules corresponded to two conspicuous pyrenoids surrounded by starch (Fig. 2a). Other distinctive features at TEM were the thick cell wall, not covered with scales, and the presence of a mitochondrial protrusion into the pyrenoid. Based on these features, these coccoids were tentatively identified as Pycnococcus provasolii (Guillard et al. 1991). The latter species has a single chloroplast but, due to its phased cell cycle, most cells divide during the day showing two pyrenoids and often two distinct hemispherical chloroplasts (Guillard et al. 1991). During the ItalianChilean expedition in the Straits of Magellan in autumn 1995, live material of the same coccoid species was obtained from the area of Paso Ancho. This material allowed to obtain better images (Fig. 2b-d) that confirmed the first identification of the species. New observations also showed the presence of the peculiar operculum-like structure on the cell surface (Fig. 2b, c), which has only been described for P. provasolii (Guillard et al. 1991), as well as chloroplasts with thylakoids arranged in a very regular pattern (Fig. 2d). Other specimens in TEM samples were identified as Bathycoccus prasinos (Fig. 2e), a coccoid prasinophyte that is distinguishable from $P$. provasolii and other coccoids by its peculiar shape, smaller $(1.5-2.5 \times 1-2 \mu \mathrm{m})$ size, and especially for the presence of spider-web scales arranged in an imbricated pattern on the cell surface (Eikrem and Throndsen 1990).

Small flagellates were mostly undetermined. Among them, cryptophyceans of two different sizes (ca $5 \mu \mathrm{m}$ and ca $12 \mu \mathrm{m}$ length, respectively) could be distinguished. Several cells showed the peculiar structures consisting of five filaments that are typical of several Phaeocystis species (Medlin and Zingone 2007), but the identification of this species was not consistent among the samples, as such structures were found either close to flagellated cells or free in the samples. TEM observations revealed the presence of other 
Table 1 List of phytoplankton taxa and ataxonomic groups identified in the Straits of Magellan in summer 1991 with mean cellular volumes, ESD and carbon content

\begin{tabular}{|c|c|c|c|}
\hline & Volume $\left(\mu \mathrm{m}^{3}\right)$ & $\operatorname{ESD}(\mu \mathrm{m})$ & Carbon (pg) \\
\hline \multicolumn{4}{|l|}{ Diatoms } \\
\hline Asterionellopsis glacialis (Castracane) Round & 300 & 8.31 & 29.4 \\
\hline Chaetoceros brevis Schütt & 1,783 & 15.04 & 124.6 \\
\hline Chaetoceros convolutos Castracane & 3,927 & 19.57 & 171.1 \\
\hline Chaetoceros curvisetus Cleve & 714 & 11.09 & 59.3 \\
\hline Chaetoceros debilis Cleve & 798 & 11.51 & 64.9 \\
\hline Chaetoceros minimus (Levander) Marino, Giuffré, Montresor et Zingone & 34 & 4.03 & 5.1 \\
\hline Chaetoceros socialis Lauder & ND & ND & ND \\
\hline Chaetoceros cf. tenuissimus Meunier & 26 & 3.66 & 4.0 \\
\hline Chaetoceros sp. & 734 & 11.19 & 60.7 \\
\hline Coscinodiscus sp. & 13,059 & 29.22 & 493.3 \\
\hline Cyclotella sp. & 120 & 6.13 & 14.0 \\
\hline Cylindrotheca closterium (Ehrenberg) Reimann et Lewin & 169 & 6.86 & 18.5 \\
\hline Detonula pumila & 13,138 & 29.28 & 495.9 \\
\hline Guinardia delicatula (Cleve) Hasle & 4,902 & 21.08 & 208.1 \\
\hline Lauderia annulata Cleve & 29,531 & 38.35 & $1,012.3$ \\
\hline Lennoxia faveolata Thomsen et Buck & 9 & 2.55 & 1.7 \\
\hline Leptocylindrus danicus Cleve & 1,442 & 14.02 & 104.9 \\
\hline Leptocylindrus sp. & 68 & 5.06 & 8.8 \\
\hline Melosira cf. sulcata (Ehrenberg) Kützing & 3,000 & 17.89 & 135.0 \\
\hline Minidiscus trioculatus Hasle & 24 & 3.58 & 3.8 \\
\hline Proboscia alata (Brightwell) Sundström & ND & ND & ND \\
\hline Pseudo-nitzschia delicatissima group & 121 & 6.14 & 14.1 \\
\hline Pseudo-nitzschia seriata group & 1,241 & 13.33 & 92.9 \\
\hline Pseudo-nitzschia sp. & 42 & 4.33 & 6.0 \\
\hline Rhizosolenia setigera Brightwell & 2,702 & 17.28 & 174.6 \\
\hline Rhizosolenia sp. & 16,799 & 31.78 & 615.9 \\
\hline Thalassionema nitzschioides (Grunow) Mereschkowsky & 480 & 9.71 & 43.0 \\
\hline Thalassiosira cf. aestivalis Gran & ND & ND & ND \\
\hline Thalassiosira cf. mendiolana Hasle et Heimdal & 16,343 & 31.49 & 601.1 \\
\hline Thalassiosira sp. cl & 8,387 & 25.21 & 334.0 \\
\hline Thalassiosira sp. & 3,135 & 18.16 & 140.3 \\
\hline Undetermined Cymatosiraceae & 15 & 3.09 & 2.7 \\
\hline Undetermined centric diatoms $<3 \mu \mathrm{m}$ (mostly $M$. trioculatus) & 11 & 2.77 & 2.0 \\
\hline Undetermined centric diatoms 3-5 $\mu \mathrm{m}$ (mostly M. trioculatus) & 28 & 3.77 & 4.3 \\
\hline Undetermined centric diatoms $<10 \mu \mathrm{m}$ & 69 & 5.09 & 8.9 \\
\hline Undetermined centric diatoms $>10 \mu \mathrm{m}$ & 3,566 & 18.96 & 157.2 \\
\hline Undetermined pennate diatoms $<15 \mu \mathrm{m}$ & 68 & 5.06 & 8.8 \\
\hline Undetermined pennate diatoms $>15 \mu \mathrm{m}$ & 5,846 & 22.35 & 243.0 \\
\hline \multicolumn{4}{|l|}{ Dinoflagellates } \\
\hline Alexandrium cf. tamarense (Lebour) Balech & 6,371 & 23.00 & 807.5 \\
\hline Dinophysis acuminata Claparède et Lachmann & 4,320 & 20.21 & 560.7 \\
\hline Dinophysis sp. & 10,539 & 27.20 & $1,295.4$ \\
\hline Ebria tripartita (Schumann) Lemmermann & 10,228 & 26.93 & $1,259.5$ \\
\hline Gonyaulax spinifera (Claparède et Lachmann) Diesing & 15,438 & 30.89 & $1,853.9$ \\
\hline Gonyaulax sp. & 21,872 & 34.70 & $2,571.4$ \\
\hline Gymnodinium sp. & 6,635 & 23.31 & 838.9 \\
\hline Gyrodinium sp. & 17,698 & 32.33 & $2,107.6$ \\
\hline
\end{tabular}


Table 1 continued

\begin{tabular}{|c|c|c|c|}
\hline & Volume $\left(\mu \mathrm{m}^{3}\right)$ & $\operatorname{ESD}(\mu \mathrm{m})$ & $\overline{\text { Carbon (pg) }}$ \\
\hline Heterocapsa triquetra (Ehrenberg) Stein & 1,407 & 13.90 & 195.5 \\
\hline Lessardia elongata Saldarriaga et F.J.R. Taylor & 895 & 11.96 & 127.9 \\
\hline Mesoporos perforatus (Gran) Lillick & 1,424 & 13.96 & 197.8 \\
\hline Neoceratium furca (Ehrenberg) Gómez, Moreira et López-Garcia & ND & ND & ND \\
\hline Neoceratium lineatum (Ehrenberg) Gómez, Moreira et López-Garcia & ND & ND & ND \\
\hline Oxytoxum cf. laticeps Schiller & 1,357 & 13.74 & 189.0 \\
\hline Oxytoxum variabile Schiller & 476 & 9.69 & 70.7 \\
\hline Oxytoxum sp. & 1,770 & 15.01 & 242.6 \\
\hline Prorocentrum minimum (Pavillard) J. Schiller & 372 & 8.92 & 56.1 \\
\hline Prorocentrum cf. rotundatum Schiller & 3,517 & 18.87 & 462.2 \\
\hline Prorocentrum vaginulum (Ehrenberg) Dodge & 399 & 9.14 & 59.9 \\
\hline Protoperidinium sp. & 10,161 & 26.87 & $1,251.7$ \\
\hline Scrippsiella sp. & ND & ND & ND \\
\hline Undetermined naked dinoflagellates $<15 \mu \mathrm{m}$ & 377 & 8.97 & 56.8 \\
\hline Undetermined naked dinoflagellates $>15 \mu \mathrm{m}$ & 3,570 & 18.96 & 468.7 \\
\hline Undetermined thecate dinoflagellates $<15 \mu \mathrm{m}$ & 519 & 9.97 & 76.7 \\
\hline Undetermined thecate dinoflagellates $>15 \mu \mathrm{m}$ & 3,774 & 19.32 & 493.9 \\
\hline \multicolumn{4}{|l|}{ Prymnesiophyceans } \\
\hline Acanthoica quattrospina Lohmann & 268 & 8.00 & 41.2 \\
\hline Calciosolenia murrayi Gran & ND & ND & ND \\
\hline Chrysochromulina sp. & ND & ND & ND \\
\hline Emiliania huxleyi (Lohmann) Hay et Mohler & 54 & 4.69 & 9.2 \\
\hline Ophiaster sp. & 82 & 5.39 & 13.5 \\
\hline Phaeocystis sp. & ND & ND & ND \\
\hline Undetermined coccolithophores & 150 & 6.59 & 23.9 \\
\hline \multicolumn{4}{|l|}{ Cryptophyceans } \\
\hline Undetermined cryptophyceae & 227 & 7.57 & 35.3 \\
\hline \multicolumn{4}{|l|}{ Chrysophyceans } \\
\hline Apedinella spinifera (Throndsen) Throndsen & 180 & 7.00 & 28.3 \\
\hline Dinobryon faculiferum (Willén) Willén & 20 & 3.35 & 3.5 \\
\hline Dinobryon sp. & 28 & 3.78 & 5.0 \\
\hline Ollicola vangoori (Conrad) Vørs & 15 & 3.06 & 2.7 \\
\hline \multicolumn{4}{|l|}{ Prasinophyceans } \\
\hline Bathycoccus prasinos Eikrem et Throndsen & ND & ND & ND \\
\hline Mamiella gilva (Parke \& Rayns) Moestrup & ND & ND & ND \\
\hline Micromonas pusilla (Butcher) Manton et Parke & ND & ND & ND \\
\hline Pycnococcus provasolii Guillard & 8 & 2.52 & 1.6 \\
\hline Pyramimonas grossii Parke & ND & ND & ND \\
\hline Pyramimonas sp. & 90 & 5.56 & 14.8 \\
\hline \multicolumn{4}{|l|}{ Euglenophyceans } \\
\hline Undetermined Euglenophyceae & 1,791 & 15.07 & 245.2 \\
\hline Eutreptiella sp. & 641 & 10.70 & 93.4 \\
\hline \multicolumn{4}{|l|}{ Dictyochophyceans } \\
\hline Dictyocha speculum Ehrenberg & 1,767 & 15.00 & 242.2 \\
\hline \multicolumn{4}{|l|}{ Filosea } \\
\hline Paulinella ovalis Wulff (Johnson, Hargraves et Sieburth) & 14 & 3.00 & 2.6 \\
\hline \multicolumn{4}{|l|}{ Other flagellates } \\
\hline Undetermined flagellates $<10 \mu \mathrm{m}$ & 22 & 3.46 & 3.9 \\
\hline Undetermined flagellates $>10 \mu \mathrm{m}$ & 950 & 12.20 & 135.3 \\
\hline
\end{tabular}

$N D$ not determined 

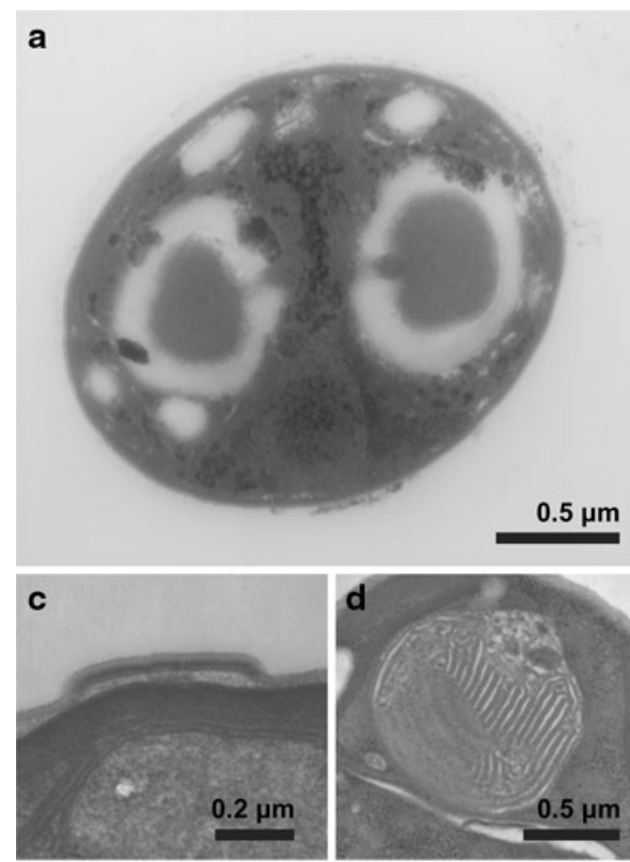

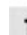

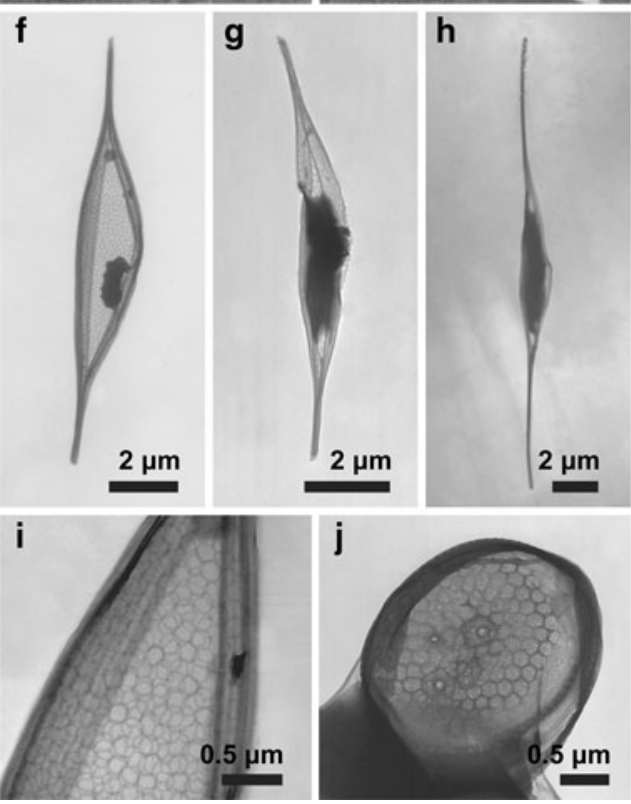

Fig. 2 EM micrographs of some of the most interesting phytoplankton species of the SOM in late summer 1991. a-d Pycnococcus provasolii. a Cell from a natural sample, note the two pyrenoids within the chloroplasts. b Cell from a serial dilution culture with the mitochondrion penetrating the pyrenoid (arrowed). $\mathbf{c}$ Detail of the operculum.

species hardly detectable in light microscopy, including Micromonas pusilla, Pyramimonas grossii, Mamiella gilva and some undetermined Chrysochromulina species.

Coccolithophores were mainly represented by the widespread species Emiliania huxleyi. Dinoflagellates were unidentified naked forms generally small $(<10 \mu \mathrm{m})$, which may also have included heterotrophic species. A few larger dinoflagellates species were identified in the area close to the Pacific entrance, among which the naked species b
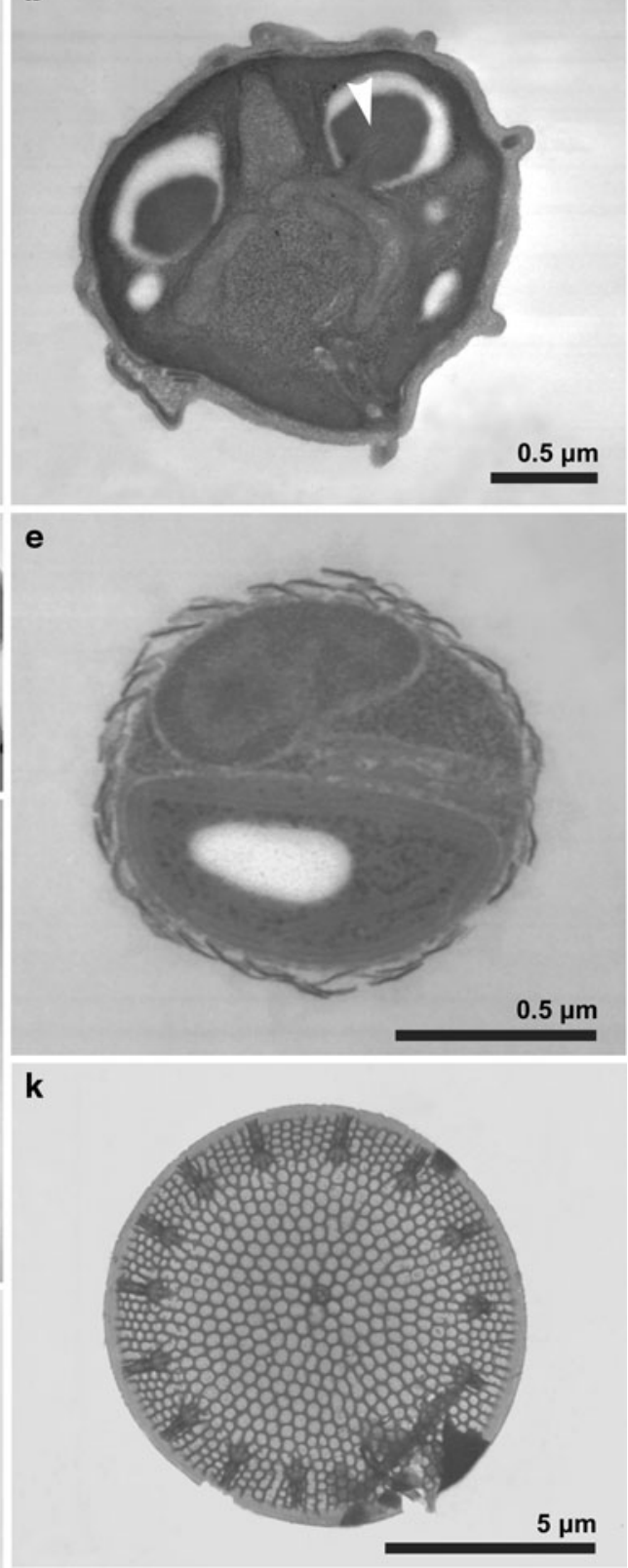

d Detail of a section of the chloroplast without the pyrenoid. e Bathycoccus prasinos from a natural sample. $\mathbf{f}-\mathbf{i}$ Lennoxia faveolata. $\mathbf{f}-\mathbf{h}$ Different frustule shapes. i Detail of the characteristic arrangement of the areolae. $\mathbf{j}$ Minidiscus trioculatus. $\mathbf{k}$ Thalassiosira $\mathrm{cf}$. aestivalis

Lessardia elongata (syn. Gymnodinium elongatum), and the thecate species Mesoporos perforatus, Oxytoxum laticeps, Prorocentrum cf. rotundatum and $P$. vaginulum.

Lennoxia faveolata (Fig. 2f-i) and Minidiscus trioculatus (Fig. 2j) were among the most common diatom species. The former has solitary, spindle-shaped cells, with a central widening and very thin rostra at the two ends. Lennoxia faveolata is not very different in shape from the pennate form of Phaeodactylum tricornutum (e.g. the specimens in 
Fig. $2 \mathrm{f}-\mathrm{g}$ ) or from small forms of the widespread pennate species Cylindrotheca closterium (e.g. the specimens in Fig. 2h). However, at TEM, it shows a quite unusual ultrastructure, with hexagonal areolae and a rudimental tubular process on one of the valves (Fig. 2i). The species was considered related to the Cymatosiraceae (Thomsen et al. 1993), a centric diatom family including several very small and polymorphic species, at times superficially resembling pennate species (Hasle et al. 1983). In the SOM, specimens of L. faveolata were straight, with rostra of medium length and total length of 7.5-26.5 $\mu \mathrm{m}$ (average $12.5 \mu \mathrm{m}$ ). Only a few specimens showed the curved forms described for the type material from the Beagle Channel by Thomsen et al. (1993). The latter is the only paper so far recording L. faveolata.

In the area of Paso Ancho, a relatively high number of small diatom cells showed a cylindrical shape. These forms, tentatively identified as Leptocylindrus sp.1 in Marino et al. (1993), at TEM rather resembled the cylindrical morph of some polymorphic cymatosiraceans, e.g. of the genera Minutocellus and Extubocellulus (Hasle et al. 1983). Unfortunately, the ultrastructure of the frustules of these specimens was not visible in TEM, preventing a better classification. Another diatom had cylindrical cells forming short colonies similar to those of Leptocylindrus spp., but much thinner (ca $2 \mu \mathrm{m}$ ), shorter (ca $15 \mu \mathrm{m}$ ) and with one single, long chloroplast. These forms are tentatively attributed to Leptocylindrus sp.

Microplanktonic $(>20 \mu \mathrm{m})$ and colonial diatoms were found in small numbers and almost exclusively at the two entrances to the SOM. On the Pacific side, they were mainly constituted by Chaetoceros debilis, Lauderia annulata, Pseudo-nitzschia cf. delicatissima, P. cf. seriata, Guinardia delicatula and Thalassiosira cf. aestivalis (Fig. 2k). In the area under the influence of Atlantic waters, Guinardia delicatula was again present, along with Leptocylindrus sp., Cylindrotheca closterium, Chaetoceros spp. and with some pennate species probably of benthic origin.

\section{Spatial distribution of phytoplankton assemblages}

Surface phytoplankton concentrations varied from minima

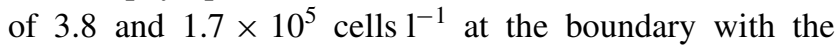
Pacific and Atlantic Oceans, respectively, to maxima of up to $1.3 \times 10^{7}$ cells $1^{-1}$ in the Patagonian sector (Fig. 3a). Spatial trends for total biomass (as carbon content) generally reflected those for cell numbers, despite some discrepancies due to differences in size and biomass values among species (Fig. 3b). For example, due to the presence of relatively large dinoflagellates, at the Pacific entrance (St. 1-5), cell numbers were much lower than those of Sector B stations but biomass values were comparable.

Based on phytoplankton density, biomass and composition, different areas could be identified in the SOM, which broadly corresponded to the sectors delineated in Saggiomo et al. (1994), although with some differences (Fig. 3). At the Pacific entrance to the Straits (St. 1, 4 and 5), phytoplankton did not exceed $7.6 \times 10^{5}$ cells $\mathrm{l}^{-1}$ but biomass values reached $17.6 \mu \mathrm{g} \mathrm{Cl}^{-1}$, due to the higher contribution of dinoflagellates, mainly naked forms $>15 \mu \mathrm{m}$. Unidentified phytoflagellates, coccolithophores (mainly Emiliania huxleyi) and coccoid cells, most of which belonging to Pycnococcus provasolii, were predominant in terms of cell numbers. Diatoms were less abundant and were represented by small undetermined centric species, Lennoxia faveolata, and some colonial species (e.g. Chaetoceros debilis, Pseudo-nitzschia spp. and Guinardia delicatula), not found in the rest of the Straits.

In the Andean section, between St. 6 and 10, cell numbers increased $\left(2.6-6.5 \times 10^{6}\right.$ cells $\left.^{-1}\right)$, while biomass values were not much higher than at the Pacific entrance (average $16.9 \pm 5.5 \mu \mathrm{g} \mathrm{C}^{-1}$ ). This area corresponded to sector B in Saggiomo et al. (1994), which however also included St. 5 and 11. Pycnococcus provasolii was strongly predominant (from 79 to $96 \%$ ) in terms of cell numbers. All the other phytoplankton groups were scarcely represented in terms of cell numbers, but small and $>15 \mu \mathrm{m}$ dinoflagellates contributed 45.9 and $46.8 \%$ of the total biomass at St 7 and 8 , while small flagellates attained $25.7 \%$ at St. 7 (Fig. 3b). Diatoms were represented only by small centric species, mainly Minidiscus trioculatus $\left(<2.3 \times 10^{5}\right.$ cells $1^{-1}$ ) and Lennoxia faveolata, the latter with much lower abundance $\left(<2.3 \times 10^{3}\right.$ cells $\left.1^{-1}\right)$.

From St. 11-13, roughly corresponding to sector $\mathrm{C}$ in Saggiomo et al. (1994), lower cell abundance (2.0$3.7 \times 10^{6}$ cells $^{-1}$ ) and very low biomass values of 6.4 $8.9 \mu \mathrm{g} \mathrm{C}^{-1}$ were recorded. At St. 11 and $11 \mathrm{bis} P$. provasolii reached its maximum relative importance in both cell numbers $(95.8 \%$ at St. 11 b) and biomass $(76.5 \%$ at St. 11$)$. Eastward (St. 12 and 13) this species was still dominant (>78\%), but phytoflagellates and diatoms (mainly undetermined cymatosiraceans and Lennoxia faveolata) increased up to 7.7 and $9.8 \%$ of the total cell number, respectively.

The numerical importance of phytoflagellates and diatoms increased notably from St. 14 to 20 (sector D in Saggiomo et al. (1994)), where the highest values for cell concentration and biomass were recorded. Diatoms attained $40.6 \%$ of the total cell number and were mainly represented by $2.6-3.6 \mu \mathrm{m}$ (ESD) solitary species, such as Lennoxia faveolata and Minidiscus trioculatus and by $<3 \mu \mathrm{m}$ ESD cylindrical cymatosiraceans. In terms of biomass, diatoms were largely outweighed by small flagellates, among which cryptohyceans were rather abundant (up to $4.9 \times 10^{5}$ cell $^{-1}$ at St. 16) and by dinoflagellates $<10 \mu \mathrm{m}$, while $P$. provasolii, although still abundant, represented only $8.7-25.5 \%$ of the total biomass.

Cell numbers and biomass values decreased from St. 21 to 23 , in the area identified as sector E by Saggiomo et al. 
Fig. 3 Surface phytoplankton distribution across the SOM in late summer 1991. The bars on the $x$ axis and the letters $A-E$ mark the sectors identified in Saggiomo et al. (2004), who did not study St. 13 and St. 24-26. a cell abundance (bars) and Percentage Similarity Index (PSI, line). $\mathbf{b}$ biomass as carbon content. c contribution of different size classes to phytoplankton carbon (bars) and mean Equivalent Spherical Diameter $(E S D$, line $)$

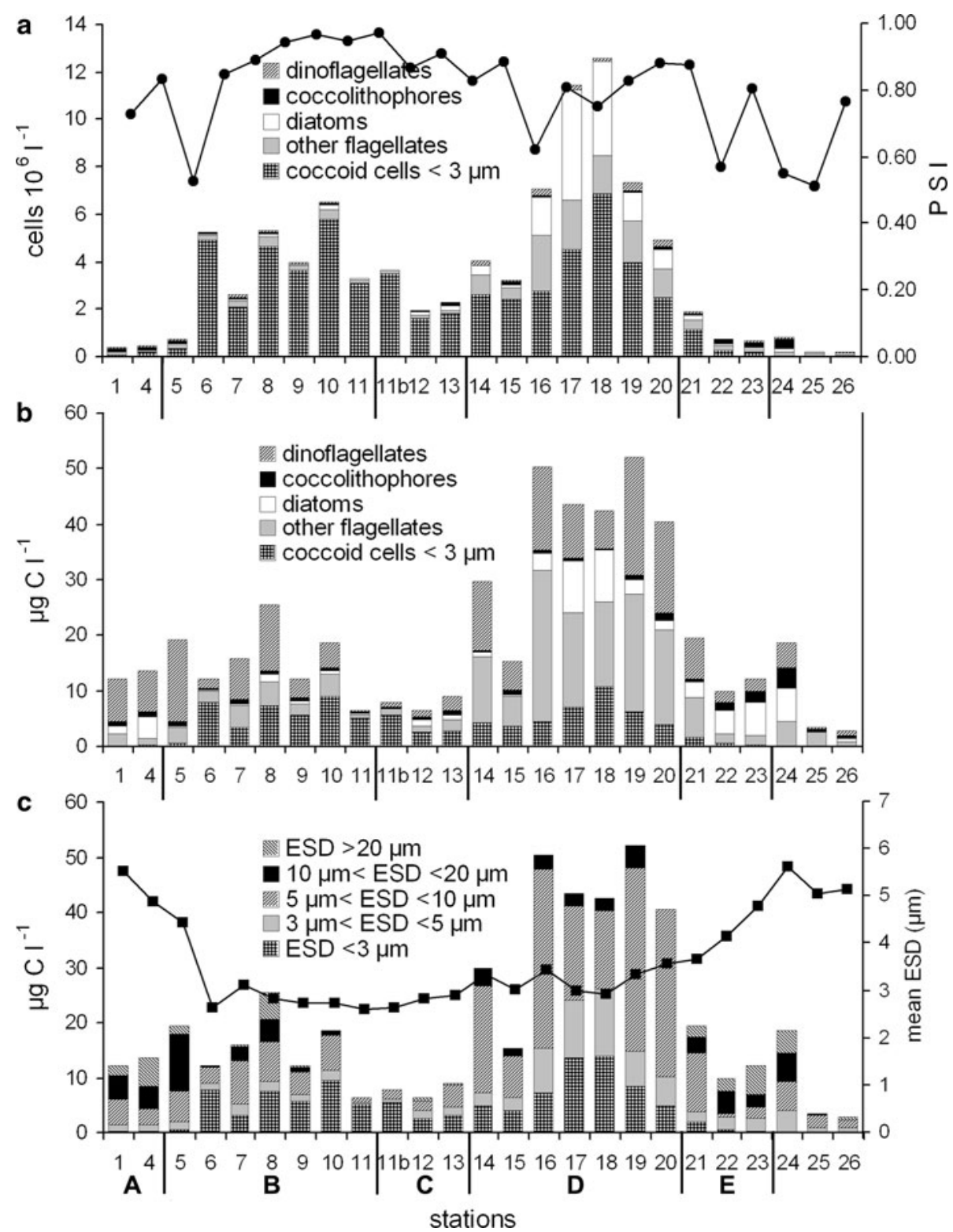

(1994), and even more so from St. 24 to 26, which were not analysed in that study. In this part of the Straits, where the Atlantic tides play a very important role, coccoid cells briskly decreased disappearing from St. 24 eastward, whereas Emiliania huxleyi and other coccolithophores reached their maximum abundance and biomass $\left(3.9 \times 10^{5}\right.$ cells $1^{-1}$ and $3.6 \mu \mathrm{g} \mathrm{C}^{-1}$ at St. 24). The small diatoms found in Paso Ancho and Bahia Inutil were substituted by other

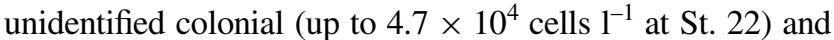
pennate species (up to $1.0 \times 10^{4}$ cells $1^{-1}$ ), along with $C y$ lindrotheca closterium, Chaetoceros spp. and Guinardia delicatula. A notable amount of detritus also characterised samples collected in the easternmost sector of this area, where minimum abundances and biomass values were recorded.

Due to the wide distribution of a relatively high number of species and suprageneric groups across the Straits, the
Percentage Similarity Index (PSI) values between adjacent stations were relatively high (Fig. 3a), with minima of 0.50-0.60 only at the Pacific entrance, between Paso Ancho and Bahia Inutil and in the area under the influence of Atlantic waters. PSI values were high even between couples of stations quite far among them (e.g. 0.94 between St. 8 and St. 12, and 0.67 between St. 8 and St. 19).

In terms of cell size, microplanktonic cells (by definition $>20 \mu \mathrm{m}$ ) were rare and scarcely contributing to the total biomass across the SOM (Fig. 3c). Within the nanoplankton, the 10 - to $20-\mu \mathrm{m}$ fraction was the least represented. From St. 6 to St. 20, 75-100\% of the total biomass was constituted by cells with a mean equivalent spherical diameter (ESD) lower than $10 \mu \mathrm{m}$. This size class included the coccoids and almost all the diatoms of the Straits, as well as the large majority of dinoflagellates and other flagellates. The 
fraction with ESD smaller than $3 \mu \mathrm{m}$, which included P. provasolii and the diatoms Minidiscus trioculatus and Lennoxia faveolata, constituted, as an average $37.1 \pm 20.9 \%$ of the total biomass from St. 6 to St. 20, briskly declining at the two entrances to the SOM. The average ESD for the whole phytoplankton assemblages varied from 2.59 to $3.57 \mu \mathrm{m}$ from St. 6 to St. 20, with the lowest values at stations where coccoid cells and diatoms were dominant (Fig. 3c). At the Pacific entrance to the Straits, as well as at stations dominated by Atlantic tides, the mean ESD briskly raised to values higher than $4 \mathrm{um}$, due to both the decrease in small cells and the presence of larger diatoms and dinoflagellates.

In addition to Pycnococcus provasolii, only missing at the easternmost stations (Fig. 3a), a number of taxa identified in this study had a wide distribution and comparable cell densities all over the Straits (Fig. 4). These included Emiliania huxleyi, Minidiscus trioculatus and undetermined cryptophyceans. Lennoxia faveolata was also widespread, except in the easternmost Atlantic region, but was more abundant in the Paso Ancho area. Other centric species (mainly cymatosiraceans) were almost absent outside the Paso Ancho area, while typically colonial diatoms (e.g. Guinardia delicatula and Chaetoceros spp.) were only retrieved at the two entrances of the SOM and benthic pennate diatoms mainly at the stations influenced by Atlantic tides.

In most cases, cell abundance was rather homogeneous over the upper $20-25 \mathrm{~m}$ of the water column, briskly decreasing only at $1-2 \%$ of the surface PAR (Fig. 5). Despite a few exceptions, species composition did not vary significantly along the vertical, showing, for example, a quite even distribution of Pycnococcus provasolii in the photic zone in most cases. However, even within stations in the same sector or with high PSI, such as St. 11b and 13 or St. 17 and 20, vertical patterns were at times different, probably reflecting small-scale hydrographic differences. In Paso Ancho and Bahia Inutil (St. 17 and 18), a decreasing vertical gradient was evident for cell numbers but not for biomass, which was homogeneous along the vertical at St. 17 but showed a subsurface maximum at St. 18 due to the higher importance of dinoflagellates in subsurface layers. At St. 4, a peak was observed at $25 \mathrm{~m}$ that was mainly constituted by unknown coccoid cells of about $1.5 \mu \mathrm{m}$ diameter, which could have been Bathycoccus prasinos, also retrieved in TEM samples.

\section{Discussion}

The importance of small-sized phytoplankton

Phytoplankton of the SOM in summer 1991 showed rather unique features in terms of community structure, species composition and abundance and biomass partitioning among size classes, which are hardly comparable to known
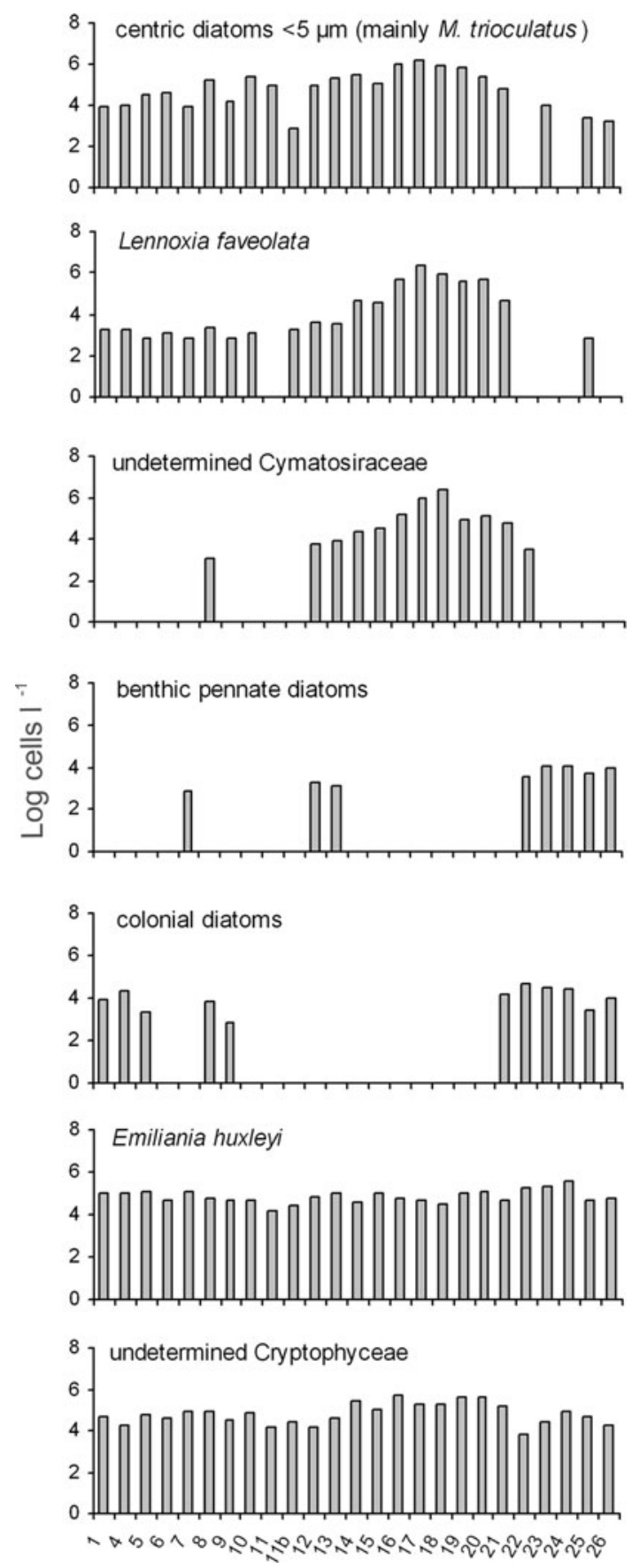

Fig. 4 Surface distribution of selected abundant taxa in the SOM in late summer 1991

phytoplankton assemblages of other subantarctic or periantarctic areas. The unifying feature all across the internal part of the Straits was the predominance of a restricted number of small-sized species, which matched the previous estimation of $95 \%$ of the total chl $a$ in the size fraction smaller than $10 \mu \mathrm{m}$ (Saggiomo et al. 1994). The most abundant species were small, non-colonial, non-motile and mostly rounded. This striking morphological convergence 


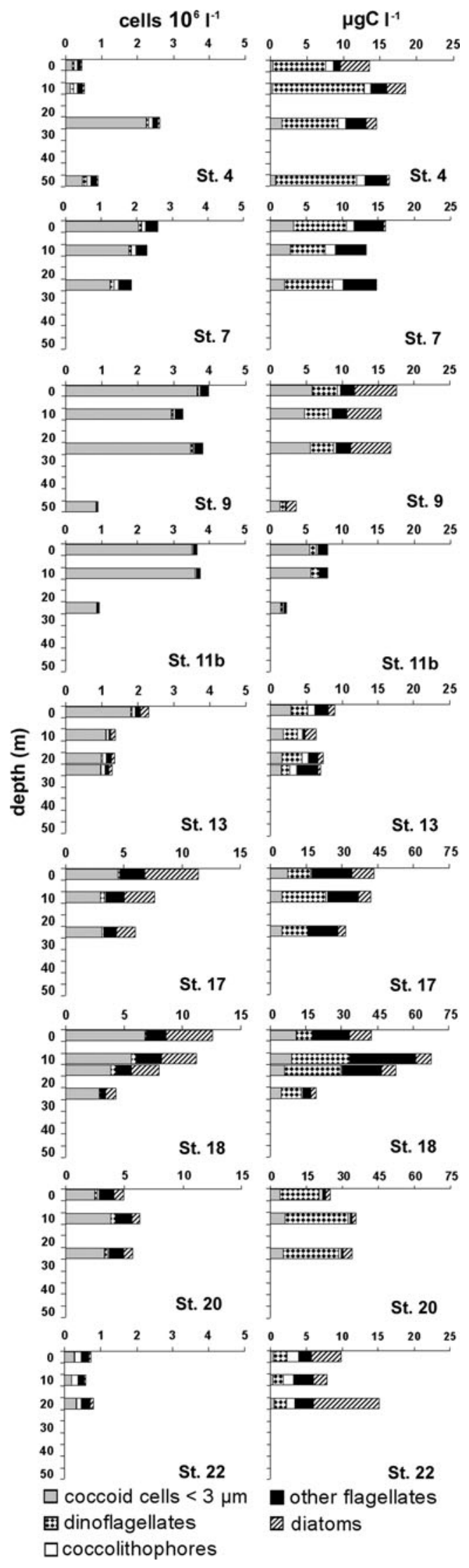

Fig. 5 Vertical distribution of phytoplankton species groups as cell numbers (left column) and carbon content (right column) at selected stations of the SOM in late summer 1991

for species belonging to different groups (diatoms, prasinophytes, coccolithophores) points at some environmental constraint, possibly of hydrodynamic or biogeochemical nature, or both. Interestingly, the dominance of small cells in the SOM in the summer of 1991 was not associated with low cell numbers nor with minimum biomass concentrations. Particularly in the Patagonian sectors of the SOM, chl $a$ values higher than $2 \mu \mathrm{g} \mathrm{l}^{-1}$ and primary production exceeding $1 \mathrm{~g} \mathrm{C} \mathrm{m}^{-2} \mathrm{~d}^{-1}$ reflected the coastal nature of the SOM, which in summer is characterised by continuous nutrient supply from run-off. Relatively high biomass coupled with small-sized phytoplankton challenge the general rule of the dominance of picoeukaryotes and nanoplankton in presence of low chl $a$ values, while microplanktonic and colonial diatoms should be responsible of biomass accumulation (e.g. Li 2002; Siokou-Frangou et al. 2010). In the Atlantic sector of the Southern Ocean, for example, the contribution of picoplankton and nanoflagellates dropped from 70 to $80 \%$ to less than $50 \%$ in areas with chl $a$ concentrations $>0.8 \mu \mathrm{g}^{-1}$ (Detmer and Bathmann 1997). The lack of large, colonial diatoms in those cases was explained with limitation by either iron or silicates or both (Boyd 2002). Within the SOM, iron limitation cannot be ruled out but is however unlikely due to the coastal nature of the site, with continuous inputs from land and strong winds presumably carrying terrestrial dust that is generally rich in this mineral. Silicates were not measured during the summer of 1991, but they were rather low (1.84-0.86 $\mu \mathrm{M}$ at $0 \mathrm{~m}$ ) in summer 1993 (Braun et al. 1993 in Iriarte et al. 2001). In the latter period, a Si:N ratio of ca 0.7 (Osses and Braun 1994 in Iriarte et al. 2001) pointed at a fast silicate depletion with consequent changes in the species composition (Iriarte et al. 2001). The marked stratification of the water column in both the Andean and Patagonian sectors (Saggiomo et al. 1994) could also have concurred in selecting out large colonial species that tend to sink more easily in these conditions, especially in case of nutrient depletion. Grazing could have also played a role in shaping the rather unique species association of the SOM, as it was apparently rather effective at least in the Patagonian sector based on ratios of degraded chlorophyll types (Saggiomo et al. 1994).

The actual importance of the small eukaryotes relative to the total picoplankton in summer 1991 is hard to quantify. Epifluorescence counts showed that the abundance of cyanobacteria in the summer 1991 cruise was one order of magnitude higher than that of picoeukaryotes $\left(10^{8}-10^{9}\right.$ and 
$10^{6}-10^{7}$ cells $^{-1}$, respectively; Bruni et al. 1993). These data match those showing that the $0.5-$ to $1.0-\mu \mathrm{m}$ chl $a$ fraction, presumably including only cyanobacteria, was more important than the 1-2 $\mu \mathrm{m}$ one (Saggiomo et al. 1994; Magazzù et al. 1996). On the other hand, very small eukaryotes are not found exclusively in the 1- to $2-\mu \mathrm{m}$ size fraction. The prasinophytes Bathycoccus prasinos and Micromonas pusilla can pass the $1-\mu \mathrm{m}$ pores of the filters, while other species, e.g. P. provasolii (average size $2.5 \mu \mathrm{m}$ ), could be easily found in the fraction larger than $2 \mu \mathrm{m}$. In addition, picoeukaryotes can be underestimated even in epifluorescence, due to their faint and quickly fading red signal, and were certainly underestimated in our light microscopy counts on fixed material, as most of them cannot be preserved and the remainders are close to the lower limit of detection with the method and magnification used. All considered picoeukaryotes may have played a major role in the SOM in summer 1991, also because they have larger cell biovolume and generally higher growth and production rates when compared to cyanobacteria (see, e.g. Worden et al. 2004).

It is also difficult to establish whether the small cells observed in the SOM in summer 1991 are a typical component of the phytoplankton of the area in other seasons as well, or they are rather found only in summer. Generally, nanoflagellates and picoeukaryotes are considered to be a stable component of phytoplankton in absolute terms, while their relative abundance varies over the seasons in the year. By contrast, peaks of flagellates were reported in the SOM in summer and early spring (Cabrini and Fonda Umani 1991; Iriarte et al. 2001), whereas the contribution of cells $<2 \mu \mathrm{m}$ (including cyanobacteria) to the total chl $a$ varied in both percentage and absolute values over the seasons. In fact, absolute and relative picoplankton chl $a$ values in summer 1991 were higher $\left(0.25 \pm 0.13 \mu \mathrm{g} \mathrm{l}^{-1}\right.$, average 59\%) than in spring $1989\left(0.14 \pm 0.07 \mu \mathrm{g} \mathrm{l}^{-1}\right.$, average 6\%) and autumn $1995\left(0.11 \pm 0.06 \mu \mathrm{g} \mathrm{l}^{-1}\right.$, average $50 \%$; Magazzù et al. 1996). Unfortunately, information on the composition of this small-sized fraction in the SOM is scanty. In autumn 1995, prokaryotic picoplankton estimated with epifluorescence microscopy counts were still one order of magnitude more abundant than eukaryotes, and nanophytoplankton was dominated by cells with a 2-3 $\mu \mathrm{m}$ diameter (Vanucci and Mangoni 1999). Likely, these cells were again $P$. provasolii, as the strain shown in this paper was isolated from the waters of the SOM in that period, and coccoids were also recorded in cell counts at LM (Iriarte et al. 1996). However, closer taxonomic investigations on the smallest phytoplankton fraction over the year are warranted in the SOM to assess the seasonality of the species identified in summer 1991.

There is little information about the physiology and ecology of most of the tiny species found in the SOM in summer 1991. Based on immunofluorescence techniques, Campbell et al. (1994) showed that in the Gulf of Maine $P$. provasolii was relatively more abundant offshore than inshore (up to $2.5 \%$ of the total eukaryotic cells), whereas at station ALOHA (Pacific Ocean), it attained maximum concentrations at the chlorophyll maximum $\left(10^{3}-10^{5}\right.$ cells $1^{-1}$, up to $23 \%$ of the total eukaryotes). Indeed $P$. provasolii, which owes its name to its presumed association with the pycnocline (Guillard et al. 1991), was shown to be adapted to low irradiance (Iriarte and Purdie 1993), which would explain its ability to colonise deep oceanic waters. Nevertheless in summer 1991, $P$. provasolii did not show any increase with depth and was equally abundant in the Andean and Patagonian sectors, despite a significant difference in irradiance between these two subregions (Saggiomo et al.1994). On the other hand, irradiance in the SOM in late summer did not exceed $25 \mathrm{E} \mathrm{m}^{-2}$ day $^{-1}$ (Saggiomo et al. 1994) and was probably further reduced by frequent cloudiness.

It is remarkable that several species, e.g. $P$. provasolii and Emiliania huxleyi, were widespread across the SOM, despite the heterogeneity of distinct areas in terms of biomass (Saggiomo et al. 1994), POC (Carrada et al. 1994) and ciliates (Fonda-Umani and Monti 1991). This result indicates a high tolerance of these species to a wide range of hydrographic features (nutrient concentrations, light intensity, salinity, mixing), but may also points at some possible distinctive features of the SOM that would play a relevant role all across its remarkable length. On the other hand, it is difficult to ascertain to what extent the assemblages observed in summer 1991 were representative of the whole SOM. Indeed, species diversity was rather low in our investigations, due to both a relatively small number of species and to the rarity of most of them. This low diversity could be normal for the season along the main path of the SOM and could be enhanced by some distinctive constraints allowing the survival of a limited number of species in the area. A low diversity, for example, was highlighted for copepods, whose species number drastically decreased in the internal sectors of the SOM in comparison with the boundary region (Mazzocchi and Ianora 1991). Yet, total diversity in the whole SOM could actually be higher, considering that other species not found in our study could be important in the fjords or in more inshore stations, where, for example, dinoflagellates blooms have recurrently been reported (Guzmán et al. 1975; Lembeye et al.1975; Uribe 1988a, b; Uribe and Ruiz 2001).

Despite the above-mentioned characters of homogeneity, spatial differences were detected in the phytoplankton assemblages of the SOM which broadly corresponded to those traced by Saggiomo et al. (1994) and Carrada et al. (1994) based on pigments and POC, respectively. For example, clearly different assemblages were observed at 
both the entrances to the Straits. Phytoplankton in these areas are probably not representative of the nearby ocean phytoplankton, but may rather be influenced by the boundary nature of the entrances. Especially at the Atlantic boundary, the effect of the tides was relevant in determining high turbidity conditions and low phytoplankton abundances. A clear discontinuity with low cell numbers and extremely low numbers of diatoms and dinoflagellates was noticed between the Andean and Patagonian sectors (Sector C), broadly corresponding to the divergence area identified in previous studies. In the area of Paso Ancho, phytoplankton showed its maximum abundance probably in relation to non-exhausted nitrogen resources, along with stratified conditions and higher light availability and residence time when compared to the Andean sectors (Saggiomo et al. 1994).

Bahia Inutil and Paso Ancho were also the only areas of the internal part of the SOM showing a relatively high abundance of diatom species. The presence of diatoms in those stratified waters apparently contradicts the general principle that these species would only thrive in well mixed waters (Margalef 1978; Alves-de-Souza et al. 2008). However, as also discussed in the following section, in Paso Ancho and Bahia Inutil, diatoms were all very small and prevalently non-colonial, thus differing from the colonial, large-sized species mainly found at the Atlantic boundary, which typically proliferate in mixed waters. The ecology of these tiny diatom species is poorly known, but it is presumable that their silicate requirement is much lower when compared to larger species. Evidence is being gathered that some of them can actually contribute a relatively high proportion of biomass and primary production in several places, such as the upwelling waters along the California coasts (Buck et al. 2008), the North and South Pacific Ocean (Kang et al. 2003; Aizawa et al. 2005; Komuro et al. 2005), the Atlantic Ocean (Gould and Fryxell 1988) and the North Western Mediterranean Sea (Percopo et al. in press). In addition, diatoms of Paso Ancho and Bahia Inutil at times formed short colonies and generally had a more elongated shape, when compared to the rounded, solitary species found in the rest of the SOM. Again, this could be related to some either hydrodynamic or biogeochemical peculiarities of this sector of the Straits, which however cannot be disentangled based on data from a single survey, especially due to the poor ecological information on individual species in the smallest size fraction of diatoms and of nanoplankton in general. A comparable lack of ecological information also characterises the naked nano- and microplanktonic dinoflagellates that constituted a large part of the biomass at many stations of the SOM. As a group, they appear to form consistent proportion of the phytoplankton biomass also in other seasons in the SOM (Iriarte et al. 2001), or in summer in other areas of the world, e.g. the Mediterranean Sea (Siokou-Frangou et al. 2010). Considering that heterotrophic and mixotrophic species are well represented in dinoflagellates, we cannot exclude that they could significantly contribute to the consumption of the picoplankton of the area in this season.

The distinctiveness of the planktonic microflora of the SOM

The most striking peculiarity of the SOM phytoplankton in summer 1991 was its species composition. The dominant species $P$. provasolii has been recorded infrequently since its first description from deep North Atlantic and Gulf of Mexico waters (Guillard et al. 1991). Cultures of P. provasolii were isolated from several localities, including the Chilean upwelling (Le Gall et al. 2008), the Ligurian Sea (Mediterranean Sea) and the English Channel (Vaulot et al. 2008), while the only abundance data for the species are those from immunofluorescence counts in the Gulf of Maine (Atlantic Ocean) and at the station Aloha in the Pacific Ocean (Campbell et al. 1994).

The diatoms found in the SOM in summer 1991 are also hardly mentioned in other studies. Lennoxia faveolata was first found in the nearby Beagle channel in April 1986, where most cells had typically curved (crescent-shaped) valves. The straight valves of $L$. faveolata from the SOM suggest that it could even be a different species (Thomsen et al. 1993). Lennoxia faveolata was also found with high numbers $\left(5.8 \times 10^{6}\right.$ cells $\left.^{-1}\right)$ in Californian waters in winter and retrieved in West Greenland and Denmark, but it has never been recorded since its description. Actually, elongated morphs of $L$. faveolata could be confused with one of the commonest diatoms, Cylindrotheca closterium, while shorter morphs could easily be misidentified as Phaeodactylum tricornutum. Our recent observations of samples collected in 2009 in the Southern Atlantic during an iron fertilisation experiment revealed the presence of $L$. faveolata, which was probably misidentified as Cylindrotheca closterium (Assmy, pers. comm) in previous studies in this area (Assmy et al. 2007). The report of Phaeodactylum tricornutum in net phytoplankton all over the channel in November 1989 (Uribe 1991) could actually be another case of misidentification of $L$. faveolata, which could be present in the Straits also in other periods of the year. Another common picoplanktonic diatom in the SOM was Minidiscus trioculatus which, along with other tiny congeneric species, have largely been overseen in plankton investigations due to their inconspicuous and featureless aspect in LM. Other small-sized diatoms in the SOM, i.e. the tiny and almost featureless cylindrical diatoms, either single cell or colonial, were hardly attributable to known species. Indeed, the morphological variability of some small diatoms, e.g. the cymatosiraceans, is high but scarcely known 
in natural samples (Hasle et al. 1983). These morphs could be an expression of the extreme morphologic variability expressed along the life cycle of these species, but we cannot exclude that they are in fact geographical varieties of known species, with distinct morphologies in relation to peculiar hydrographic conditions in the SOM. Alternatively, they could even be new, undescribed species, only morphologically similar to known species from the northern temperate hemisphere.

Several species first reported in the SOM in this study are instead known from different latitudes and types of environment. Bathycoccus prasinos was described from deep waters from the Mediterranean Sea by Eikrem and Throndsen (1990) and was probably present in the northeastern Atlantic and in California (Johnson and Sieburth 1982). Recently, molecular methods have revealed its presence in Pacific waters (Worden et al. 2004) and in the English Channel (Marie et al. 2010). Micromonas pusilla, Mamiella gilva and Pyramimonas grossii, first identified in the SOM in our study, are also cosmopolitan, but are not frequently reported because their identification requires TEM or live material observations. The lack of reports of Emiliania huxleyi in previous studies in the SOM is surprising, but it could be due to the common use of acid fixatives that destroy calcareous plates, preventing the identification of this widespread coccolithophore. Flagellate stages of Phaeocystis sp. were recognised in light microscopy based on the presence of the typical 5-filament ejections and were also retrieved in TEM sections. However, morphological information obtained in this study did not allow a clear attribution to any species. Phaeocystis sp. has already been reported in LM studies from the SOM (Iriarte et al. 1993), probably as colonies, as these are more frequently identified at least at the genus level.

From a biogeographic point of view, the late summer SOM microflora, largely dominated by the coccoid prasinophyte $P$. provasolii and by tiny diatoms, to our knowledge does not resemble any other species association of the world's seas. The lack of comparable assemblages may depend on the geographical and hydrographic uniqueness of the SOM, which is the only continental ecosystem at that latitude. This would however affect phytoplankton composition only in this particular season of the year, since the colonial diatoms dominating the spring assemblages in the SOM are the same as those found in many other temperate coastal areas (Uribe 1991; Cabrini and Fonda Umani 1991). On the other hand, it is also possible that the dominant species found in summer 1991 in the SOM are actually widespread and abundant elsewhere, but they are not easily identified with routine methods. Indeed, molecular investigations in recent years have revealed that small prasinophytes and other tiny species are much more widespread and abundant than thought before (Not et al. 2004; Marie et al. 2005; Foulon et al. 2008). The same considerations also apply to very small diatoms, which are very difficult to identify and at times even hardly recognisable as diatoms. Therefore, the observed peculiarity of the SOM microflora in summer 1991 could simply reflect the generalised lack of information on the distribution of individual picoeukaryote species in the sea. Clearly, taxonomic investigations supported by molecular techniques are required in this interesting region to clarify the identity of the species living there and to confirm the absence of Antarctic/subantarctic and/or endemic species.

Acknowledgments This article belongs to a special topic. A number of articles appear in this issue of Polar Biology, coordinated by L. Guglielmo and V. Saggiomo, and are a result of two workshops on "The pelagic ecosystem of the Straits of Magellan" held in August 2008 and 2009 in Capo Calava' Village, Messina, Italy. The studies were conducted in the frame of the National Program of Research in Antarctica (PNRA) of Italy.

Open Access This article is distributed under the terms of the Creative Commons Attribution Noncommercial License which permits any noncommercial use, distribution, and reproduction in any medium, provided the original author(s) and source are credited.

\section{References}

Aizawa C, Tanimoto M, Jordan RW (2005) Living diatom assemblages from North Pacific and Bering Sea surface waters during summer 1999. Deep-Sea Res II 52:2186-2205

Alves-de-Souza C, Gonzalez MT, Iriarte JL (2008) Functional groups in marine phytoplankton assemblages dominated by diatoms in fjords of southern Chile. J Plankton Res 30:1233-1243

Andersen P, Throndsen J (2003) Estimating cell numbers. In: Hallegraeff GM, Anderson DM, Cembella AD (eds) Manual on harmful marine microalgae. IOC-UNESCO, Paris, pp 99-129

Anonymous (1991) Straits of magellan. Oceanographic cruise, February-March 1991. Data report. Part I: physical, chemical and biological oceanography. Ital Natl Sci Comm Ant, Genova

Antezana T (1999) Plankton of southern Chilean fjords: trends and linkages. Sci Mar 63:69-80

Antezana T, Hamamé M, Eissler Y, Jara S (1996) Traits of phyto- and zooplankton from the Strait of Magellan to Beagle Channel on board RV Victor Hensen, leg 1and 2, Oct-Nov 1994. Ber Polarforsch 190:23-33

Artegiani A, Paschini E, Andueza Calderon J (1991) Physical oceanography of the Straits of Magellan. Mem Biol Mar Oceanogr 19:11-52

Assmy P, Henjes J, Klaas C, Smetacek V (2007) Mechanisms determining species dominance in a phytoplankton bloom induced by the iron fertilization experiment EisenEx in the Southern Ocean. Deep Sea Res Part I Oceanogr Res Papers 54:340-362

Avaria SP (2008) Phytoplankton in the austral Chilean channels and fjords. In: Silva N, Palma S (eds) Progress in the oceanographic knowledge of Chilean interior waters, from Puerto Montt to Cape Horn. Com Oceanogr Nac, Pont Un Cat de Valparaíso, Valparaíso, pp 88-92

Boyd PW (2002) Environmental factors controlling phytoplankton processes in the Southern Ocean. J Phycol 38:844-861 
Braun M, Blanco JL, Osses J (1993) Investigación monitoreo de marea roja en la XII región. Final report. Instituto de Fomento Pesquero, Valparaiso

Bruni V, Crisafi E, Acosta Pomar ML, La Ferla R, Maugeri TL, Monticelli LS, Zaccone R (1993) Distribution of microbial populations in the Strait of Magellan. In: Faranda F, Guglielmo L (eds) Straits of Magellan oceanographic cruise, February-March 1991. Data Report Part II: physical, chemical and biological oceanography. Ital Natl Sci Comm Ant, Genova, pp 5-64

Buck KR, Chavez FP, Davis AS (2008) Minidiscus trioculatus, a small diatom with a large presence in the upwelling systems of central California. In: Medlin LK, Doucette GJ, Villac MC (eds) Phytoplankton evolution, taxonomy and ecology, vol 133. Cramer, Stuttgart, pp 1-6

Cabrini M, Fonda Umani S (1991) Phytoplankton populations in the Strait of Magellan. Boll Oceanol Teor Appl 9:137-144

Campbell L, Shapiro LP, Haugen E (1994) Immunochemical characterization of eukaryotic ultraplankton from the Atlantic and Pacific oceans. J Plankton Res 16:35-51

Carrada GC, Fabiano M, Povero P, Saggiomo V (1994) Surface distribution of size-fractionated chlorophyll $a$ and particulate organic matter in the Strait of Magellan. Polar Biol 14:447-454

Cloern JE (1996) Phytoplankton bloom dynamics in coastal ecosystems: a review with some general lessons from sustained investigation of San Francisco Bay, California. Rev Geophys 34:127-168

Detmer AE, Bathmann U (1997) Distribution patterns of autotrophic pico- and nanoplankton and their relative contribution to algal biomass during spring in the Atlantic sector of the Southern Ocean. Deep-Sea Res II 44:299-320

Eikrem W, Throndsen J (1990) The ultrastructure of Bathycoccus gen. nov. and B. prasinos sp. nov., a non-motile picoplanktonic alga (Chlorophyta, Prasinophyta) from the Mediterranean and Atlantic. Phycologia 29:344-350

Fabiano M, Povero P, Danovaro R, Bruzzone R (1991) Biochemical composition of particulate organic matter in the Straits of Magellan. In: Anonymous (ed) Straits of Magellan oceanographic cruise, February-March 1991. Data Report Part I: physical, chemical and biological oceanography. Ital Natl Sci Comm Ant, Genova, pp 155-167

Faranda F, Guglielmo L (eds) (1993) Straits of Magellan. Oceanographic cruise, February-March 1991. Data report. Part II: physical, chemical and biological oceanography. Ital Natl Sci Comm Ant, Genova

Fonda-Umani S, Monti M (1991) Microzooplankton populations in the Strait of Magellan. Boll Oceanol Teor Appl 9:151-162

Foulon E, Not F, Jalabert F, Cariou T, Massana R, Simon N (2008) Ecological niche partitioning in the picoplanktonic green alga Micromonas pusilla: evidence from environmental surveys using phylogenetic probes. Environ Microbiol 10:2433-2443

Gould RW, Fryxell GA (1988) Phytoplankton species composition and abundance in a Gulf Stream warm core ring. I. Changes over a five month period. J Mar Syst 46:367-398

Guillard RRL, Keller MD, O'Kelly CJ, Floyd GL (1991) Pycnococcus provasolii gen. et sp. nov; a coccoid prasinoxanthin-containing phytoplankter from the western North Atlantic and Gulf of Mexico. J Phycol 27:39-47

Guzmán L, Campodónico I, Hermosilla J (1975) Estudios sobre un florecimiento tóxico causado por Gonyaulax catenella en Magallanes. I.-Distribución espacial y temporal de G. catenella Anales Instituto de la Patagonia. Punta Arenas (Chile) 4:173-183

Hasle GR (1995) Marine diatoms. In: Tomas CR (ed) Identifying marine diatoms and dinoflagellates. Academic Press, San Diego, pp 5-385

Hasle GR, von Stosch HA, Syvertsen EE (1983) Cymatosiraceae, a new diatom family. Bacillaria 6:9-156
Heimdal BR (1993) Modern coccolithophorids. In: Tomas CR (ed) Marine phytoplankton. A guide to naked flagellates and coccolithophorids. Academic Press, San Diego, pp 147-249

Iriarte A, Purdie DA (1993) Photosynthesis and growth-response of the oceanic picoplankter Pycnococcus provasolii Guillard (clone omega-48-23) (Chlorophyta) to variations in irradiance, photoperiod and temperature. J Exp Mar Biol Ecol 168:239-257

Iriarte JL, Uribe JC, Valladares C (1993) Biomass of size-fractionated phytoplankton during the spring-summer season in southern Chile. Bot Mar 36:443-450

Iriarte JL, Basualto S, Marino D, Uribe JC (1996) Distribution of phytoplankton in the Strait of Magellan (March-April 1995). In: Faranda FM, Guglielmo L, Povero P (eds) National Program Antarctic Research, Straits of Magellan Oceanographic Cruise, March-April 1995. Data Report Lang-Art Grafique, Genova (Italy), pp 141-170

Iriarte JL, Kusch A, Osses J, Ruiz M (2001) Phytoplankton biomass in the sub-Antarctic area of the Straits of Magellan $\left(53^{\circ} \mathrm{S}\right)$, Chile, during spring-summer 1997-1998. Polar Biol 24:154-162

Iriarte JL, González HE, Liu KK, Rivas C, Valenzuela C (2007) Spatial and temporal variability of chlorophyll and primary productivity in surface waters of southern Chile $\left(41.5-43^{\circ} \mathrm{S}\right)$. Estuar Coast Shelf Sci 74:471-480

Johnson PW, Sieburth JM (1982) In situ morphology and occurrence of eukaryotic phototrophs of bacterial size in the picoplankton of estuarine and oceanic waters. J Phycol 18:318-327

Kang JS, Kang SH, Kim D, Kim DY (2003) Planktonic centric diatom Minidiscus chilensis dominated sediment trap material in eastern Bransfield Strait, Antarctica. Mar Ecol-Prog Ser 255:93-99

Komuro C, Narita H, Imai K, Nojiri Y, Jordan RW (2005) Microplankton assemblages at Station KNOT in the subarctic western Pacific, 1999-2000. Deep-Sea Res II 52:2206-2217

Le Gall F, Rigaut-Jalabert F, Marie D, Garczarek L, Viprey M, Gobet A, Vaulot D (2008) Picoplankton diversity in the South-East Pacific Ocean from cultures. Biogeosciences 5:203-214

Lembeye GV, Guzman LM, Campodónico IG (1975) Estudios sobre un florecimiento toxico causado por Gonyaulax catenella en Magallanes. III. Fitoplancton asociado. Ans Inst Pat Punta Arenas (Chile) 6 (1-2):197-208

Lembeye G, Guzman LM, Campodónico IG (1978) Fitoplancton del sector oriental del Estrecho de Magallanes, Chile (5 al 13 de abril de 1976). Punta Arenas (Chile) 9:221-228

Li WKW (2002) Macroecological patterns of phytoplankton in the northwestern North Atlantic Ocean. Nature 419:154-157

Magazzù G, Panella S, Decembrini F (1996) Seasonal variability of fractionated phytoplankton, biomass and primary production in the Straits of Magellan. J Mar Syst 9:249-267

Margalef R (1978) Life-forms of phytoplankton as survival alternatives in an unstable environment. Oceanol Acta 1:493-509

Marie D, Zhu F, Balagué V, Ras J, Vaulot D (2005) Eukaryotic picoplankton communities of the Mediterranean Sea in summer assessed by molecular approaches (DGGE, TTGE, QPCR). FEMS Microbiol Ecol 55:403-415

Marie D, Shi XL, Rigaut-Jalabert F, Vaulot D (2010) Use of flow cytometric sorting to better assess the diversity of small photosynthetic eukaryotes in the English Channel. FEMS Microbiol Rev 72:165-178

Marino D, Sarno D, Zingone A (1991) Distribution of phytoplankton populations in the Strait of Magellan (February - March 1991). Mem Biol Mar Oceanogr 19:147-150

Marino D, Zingone A, Sarno D (1993) Distribution of phytoplankton populations in the Strait of Magellan (February-March, 1991). In: Faranda F, Guglielmo L (eds) Straits of Magellan Oceanographic Cruise, February-March 1991. Data report part II: physical, chemical and biological oceanography. Ital Natl Sci Comm Ant, Genova, pp 65-135 
Mazzocchi MG, Ianora A (1991) A faunistic study of the copepod assemblages in the Strait of Magellan. Boll Oceanol Teor Appl 9:163-177

Medeiros C, Kjerfve B (1988) Tidal characteristics of the Strait of Magellan. Cont Shelf Res 8:947-960

Medlin L, Zingone A (2007) A taxonomic review of the genus Phaeocystis. Biogeochemistry 83:3-18

Menden-Deuer S, Lessard EJ (2000) Carbon to volume relationships for dinoflagellates, diatoms, and other protist plankton. Limnol Oceanogr 45:569-579

Not F, Latasa M, Marie D, Cariou T, Vaulot D, Simon N (2004) A single species, Micromonas pusilla (Prasinophyceae), dominates the eukaryotic picoplankton in the Western English Channel. Appl Environ Microbiol 70:4064-4072

Osses J, Braun M (1994) Desequilibrio estequiométrico entre el nitrógeno y el sílice en los canales de la Patagonia, XII Région. In: XIV congress of marine sciences, May 1994, Puerto Montt, Chile

Percopo I, Siano R, Cerino F, Sarno D, Zingone A (in press) Phytoplankton diversity during the spring bloom in the north-western Mediterranean Sea. Bot Mar

Saggiomo V, Goffart A, Carrada GC, Hecq JH (1994) Spatial patterns of phytoplankton pigments and primary production in a semienclosed periantarctic ecosystem: the Straits of Magellan. J Mar Syst 5:119-142

Siokou-Frangou I, Christaki U, Mazzocchi MG, Montresor M, Ribera D'Alcalà M, Vaqué D, Zingone A (2010) Plankton in the open Mediterranean Sea: a review. Biogeosciences 7:1-44

Steidinger K, Tangen K (1995) Dinoflagellates. In: Tomas CR (ed) Identifying marine diatoms and dinoflagellates. Academic Press, San Diego, pp 387-584

Thomsen HA, Buck KR, Marino D, Sarno D, Hansen LE, Ostergaard JB, Krupp J (1993) Lennoxia faveolata gen. et sp. nov. (Diatomophyceae) from South America, California, West Greenland and Denmark. Phycologia 32:278-283
Throndsen J (1993) The planktonic marine flagellates. In: Tomas CR (ed) Marine phytoplankton A guide to naked flagellates and coccolithophorids. Academic Press, San Diego, pp 7-145

Toro JE (1985) Annual cycle and composition of the phytoplankton in the Quempillen River Estuary, Southern Chile. Estuar Coast Shelf Sci 21:461-469

Uribe JC (1988a) Antecedentes sobre un tercer brote de veneno paralizante de moluscos (VPM), en la region de Magallanes. Ans Inst Pat Ser Cs Nts Punta Arenas (Chile) 18:97-101

Uribe JC (1988b) Observaciones sobre algunos fenomenos recurrentes en el fitoplancton de Seno Union y Bahia Bell (region de Magallanes) y su relacion con la estabilidad de la columna de agua. Ans Inst Pat Ser Cs Nts Punta Arenas (Chile) 18:103-111

Uribe J (1991) Net-phytoplankton distribution in the Strait of Magellan. Boll Oceanol Teor Appl 9:145-150

Uribe JC, Ruiz M (2001) Gymnodinium brown tide in the Magellanic fjords, Southern Chile. Rev Biol Mar Oceanogr 36:155-164

Utermöhl H (1958) Zur Vervollkommnung der quantitativen Phytoplankton-Methodik. Mitteilungen der Internationale Vereinigung für theoretische und angewandte Limnologie 9:1-38

Vanucci S, Mangoni O (1999) Pico- and nanophytoplankton assemblages in a subantarctic ecosystem: the Strait of Magellan. Bot Mar 42:563-572

Vaulot D, Eikrem W, Viprey M, Moreau H (2008) The diversity of small eukaryotic phytoplankton $(<3 \mu \mathrm{m})$ in marine ecosystems. FEMS Microbiol Review 32:795-820

Whittaker RH (1952) A study of summer foliage insect communities in the Great Smoky Mountains. Ecol Monogr 22:1-44

Worden AZ, Nolan JK, Palenik B (2004) Assessing the dynamics and ecology of marine picophytoplankton: the importance of the eukaryotic component. Limnol Oceanogr 49:168-179

Zingone A, Throndsen J, Forlani G (1995) Pyramimonas oltmannsii (Prasinophyceae) reinvestigated. Phycologia 34:241-249 